\title{
Formacja patriotyczna żołnierzy Polskich Sił Powietrznych na Zachodzie (1939-1945)
}

\section{PATRIOTIC AND RELIGIOUS FORMATION OF POLISH AIR FORCE SOLDIERS IN WESTERN EUROPE DURING WORLD WAR II}

All of the chaplains of the Polish Air Force in the West during World War II were Roman Catholic priests. They were delegated to the pastoral ministry of soldiers serving in air units in RAF bases, assigned to a given pastoral area. Their duties included: celebrating Sunday Masses, administration of sacraments (Baptism, Matrimony), visiting the sick and wounded in hospitals, celebrating funerals, as well as hearing confessions, everything connected with the spiritual care and support for the air force soldiers. The chaplains served Poles who fought far from their families, often without any news about them since the beginning of the war. Even if contact with their families could be established, the soldiers remained concerned and uncertain about the future of their relatives living under the German and Russian occupation. The chaplains had to make efforts to keep up the morale in the ranks. They played a significant role not only in the spiritual and religious formation of soldiers but also their patriotic formation. The purpose of this formation was to shape in them not only the mature attitude of Christian soldiers, but also a deep love for their Homeland (patriotism).

Key words: Polish Air Forces, Great Britain, France, II World War, catholic chaplain, patriotism, religious formation. 


\section{Wstęp}

Historia Polski związana jest z niemal nieustanną walką o jej wolność. Niewątpliwie motorem tej walki i troski o niepodległość był patriotyzm i umiłowanie Ojczyzny. Za tę wolność nierzadko trzeba było zapłacić wysoką cenę. Cechą charakterystyczną była walka nie tylko o naszą, lecz także o wolność innych narodów. Hasło przypisywane Joachimowi Lelewelowi wyszywano na sztandarach w trakcie zrywów narodowych XIX wieku. W pełnej wersji brzmiało: „W imię Boga za naszą i waszą wolność”. Do tego hasła odwoływali się polscy żołnierze na Węgrzech walczący pod wodzą gen. Józefa Bema, a także walczący na Wschodzie i Zachodzie na frontach II wojny światowej. Patriotyzm niewątpliwie był istotnym motorem walki o wolność i niepodległość Polaków. Warto przytoczyć słowa wypowiedziane przez europosłankę Annę Fotygę na cmentarzu Milltown w Irlandii Północnej w 2015 roku, gdzie pochowano 7 polskich lotników 304 Dywizjonu Bombowego im. „Powstańców Śląskich”: „Ci młodzi chłopcy walczyli o wolność naszą i waszą. (...) Marzyli o tym, by bronić terytorium Polski, żeby bronić swoich rodzin"1.

\section{Tworzenie struktur kapelanów wojsk polskich na Zachodzie}

Po agresji Niemiec hitlerowskich oraz Związku Radzieckiego jesienią 1939 roku na Polskę, na Zachód przedostała się dość liczna grupa polskich żołnierzy. Wśród nich znaleźli się lotnicy, personel naziemny,

History of the Church a także kapelani Wojska Polskiego. Pierwsze regularne lotnicze formacje wojskowe powstały we Francji oraz w Anglii. We Francji w lutym 1940 roku utworzono bazę lotniczą na lotnisku Lyon-Bron. Lotnicy zamieszkiwali w Lyonie oraz w okolicy. Główny punkt stanowiło Centrum Wyszkolenia Lotnictwa Polskiego (CWL) w Lyonie, gdzie stacjonował 1/45 Polski Dywizjon Myśliwski Warszawski.

Opiekę duchową dla polskich żołnierzy na Zachodzie organizował Biskup Polowy Józef Gawlina. Początkowo we Francji pracowało tylko dwóch kapelanów: ks. ppłk Leon Broel Plater i ks. mjr pil. Rafał Gogoliński-Elston. Ważną rolę w kształtowaniu postaw patriotyzmu wśród lotników Polskich Sił Powietrznych na Zachodzie odgrywali kapelani Kościoła rzymskokatolickiego. Ich posługa nie ograniczała się jedynie do przekazu wiary czy zasad moralności, lecz przede wszystkim do dawania osobistego przykładu, niesienia wiary, nadziei, a także do

1 Por. http://www3.tchr.org/modlitwy-za-polskich-pilotow-w-belfascie, dostęp 2019-1-29. 
sprawowania posługi duszpasterskiej wśród więźniów, chorych w szpitalach oraz Polaków zamieszkałych poza granicami okupowanej Ojczyzny. Morale żołnierzy, a także warunki, w których się znaleźli tuż po przybyciu do Francji czy Anglii były bardzo trudne. Warto tu zacytować fragment z dziennika ks. Mikołaja Sasinowskiego - kapelana polskich lotników. Wokół widać było załamanie wielu żołnierzy, którzy stracili zaufanie do swoich dowódców, demoralizacja, zwątpienie, pijaństwo, wszędzie brud, i wszy, nędza². Polscy żołnierze, którzy dostali się na Zachód po klęsce wrześniowej nierzadko byli rozgoryczeni i zdemoralizowani. Panował smutek, żal, obok osób głęboko wierzących czy też gorących patriotów było wielu obojętnych na los Ojczyzny lub niewierzących w jej odrodzenie, żołnierze niedarzący zaufaniem swoich dowódców, czy też osoby wrogo nastawione do religii katolickiej. Tym trudniejsze było działanie kadry oficerskiej oraz kapelanów działających nad podniesieniem i umocnieniem morale wojska.

\section{Francja}

Po klęsce kampanii wrześniowej Biskup Polowy Józef Gawlina znalazł się na uchodźstwie we Francji. Dowódcy jednostek lotniczych, m.in. płk Stanisław Luziński z bazy Lyon-Bron domagali się szybkiego przydziału kapelanów wojskowych ${ }^{3}$. Obok dwóch kapelanów (ks. ppłk Plater i ks. mjr Rafał Gogoliński), którzy w 1939 roku wraz z lotnikami przybyli do Francji, stopniowo dołączali nowi kapelani: ks. Franciszek Kącki CRL (Lyon), ks. Andrzej Żyłka TJ, ks. Maksymilian Kotowski, ks. Mikołaj Sasinowski i ks. Walenty Nowacki SJ.

Naczelnym kapelanem polskich lotników we Francji był ks. Gogoliński. Poważnym problemem duszpasterzy lotników we Francji był brak kaplic w bazach lotniczych. Początkowo Msze św. i inne nabożeństwa odprawiano w miejscowych francuskich kościołach (Lyon), w hangarach lotniczych (lotnisko Lyon-Bron), w izbach żołnierskich lub na dworze, nad rzeką (Foire). Codziennie lotnicy uczestniczyli we wspólnych modlitwach porannych i wieczornych oraz w nabożeństwach majowych. Pierwszą kaplicę w La Foire księża kapelani Kotowski i Żyłka urządzili na terenie powystawowym. Była to pierwsza katolicka kaplica dla polskich lotników we Francji, której wyposażenie

$2 \quad$ M. Sasinowski, Dziennik, 26.10.1939, mps w Archiwum Diecezjalnym w Łomży (dalej ArŁm), Akta Biskupa Mikołaja Sasinowskiego, k. 57-58.

3 Por. M. Sasinowski, Przedmowa J. E. Księdza Biskupa Dr. Mikołaja Sasinowskiego, b. kapelana P.S.P., [w:] A. F. Kowalkowski, Duszpasterstwo Polskich Sit Powietrznych we Francji i w Wielkiej Brytanii 1939-1946, „Studia Pelplińskie” 1979, s. 154. 
ufundował papież Pius XII. Ksiądz Sasinowski tuż po przybyciu do bazy Lyon Bron na polecenie ks. kapelana Rafała Gogolińskiego-Elston, wspólnie z żołnierzami urządził obozową kaplicę, którą oddano do użytku 29 lutego 1940 roku. Mógł w niej codziennie odprawiać Mszę św., spowiadać, głosić konferencje. Polscy lotnicy i kapelani zostali ewakuowani z Francji latem 1940 roku$^{4}$.

\section{Anglia}

Ksiądz ppłk Leon Broel Plater w grudniu 1939 roku wyjechał do Wielkiej Brytanii w celu objęcia stanowiska kapelana Lotnictwa Polskiego przy RAF oraz innych polskich oddziałów wojskowych ${ }^{5}$. Kapelan stacjonował w bazie lotnictwa polskiego Eastchurch, gdzie wybudowano kaplicę dla polskich lotników. Pod koniec maja 1940 roku bazę przeniesiono do Blackpool nad Morzem Irlandzkim w hrabstwie Lancashire, gdzie utworzono Centrum Wyszkolenia Ziemnego Lotniczego. Jej szefem został ks. Plater. Do Anglii przybywali nowi kapelani lotników ewakuowani z Francji. Ostatnim był ks. Mikołaj Sasinowski, który 17 lipca 1940 r. dotarł statkiem via Afryka, Gibraltar do Glasgow. Nad świeżo przybyłymi lotnikami opiekę duszpasterską kapelanów nadzorował ks. mjr Rafał Gogoliński. Kapelanem polskiego oddziału lotniczego w Afryce Zachodniej był ks. Maksymilian Kotowski ${ }^{6}$.

Służba duszpasterska Polskich Sił Powietrznych w Anglii została zreorganizowana 7 marca 1941 roku. Odtąd mieściła się przy Centrum Wyszkolenia Ziemnego w Blackpool. Jej szefem został ks. dr Ludwik Bombas, a kapelanem łącznikowym ks. ppłk Leon Broel Plater. Ksiądz mjr Rafał Gogoliński-Elston był kapelanem w rejonie Blackpool, zaś ks. Marian Konczewski w rejonie Ternhill. W lipcu 1941 roku ks. Bombas wyjechał do Kanady, natomiast na stanowisko szefa duszpasterstwa powołano ks. ppłk. Antoniego Miodońskiego.

\section{Zadania i obowiązki kapelanów wojskowych}

Obowiązki kapelanów wojskowych regulowały dokumenty wydawane przez Sztab Generalny Wojska Polskiego i przez Biskupa Polowego. Od 1933 roku był nim Józef Gawlina. Na kilka lat przed wybuchem wojny hierarcha wydał szereg zarządzeń dotyczących zadań duszpasterskich wobec żołnierzy, sprawowanie Mszy św. oraz innych

\footnotetext{
$4 \quad$ A. F. Kowalkowski, Duszpasterstwo..., s., 156-159.

5 Ibidem, s. 159.

6 Ibidem, s., 161-164.
} 
sakramentów, głoszenie kazań, w których oprócz części poświęconej wyjaśnianiu bieżącej liturgii i czytań mszalnych winny znajdować się odniesienia do kształtowania postaw moralnych, religijnych i patriotycznych żołnierzy. Ponadto do ich obowiązków należało prowadzenie ksiąg metrykalnych i sporządzanie aktów stanu cywilnego oraz opieka nad grobami wojskowych ${ }^{7}$. W czerwcu 1939 roku, na wypadek ewentualnego konfliktu militarnego, bp Gawlina wydał rozkaz, w którym przekazał kapelanom specjalne uprawnienia udzielone przez Stolicę Apostolską na czas wojny. Od chwili mobilizacji spowiedź św. żołnierzy miała być traktowana, jak korzystanie z sakramentu w niebezpieczeństwie śmierci. Kapelani mogli odprawiać dwie Msze św. dziennie bez koniecznej dyspensy, celebrować Eucharystię w warunkach polowych, czyli poza świątynią lub kaplicą, bez konieczności zachowania przepisanego postu eucharystycznego przez nich samych, jak też przez żołnierzy ${ }^{8}$. Oprócz typowych obowiązków duszpasterskich kapelanów bp Gawlina kładł szczególny nacisk na kształtowanie dyscypliny, morale oraz postaw patriotycznych żołnierzy. Zadaniem kapelanów było wzmacnianie wzajemnej więzi pomiędzy kadrą oficerską i pozostałymi żołnierzami oraz utrzymywanie bliskich kontaktów z dowódcami oddziałów. Duży nacisk kładł na osobisty przykład wiary, moralności i postawy patriotycznej duchownych, na osobiste zaangażowanie w dzieła miłosierdzia, dyspozycyjnością, służeniem dobrą radą, niesieniem nadziei i pociechy, łagodnością, łagodzeniem sporów, a także zachętą do sumiennego wykonywania rozkazów przez przełożonych. Według dyspozycji Biskupa Polowego, kapelani nie powinni pobierać ofiar od żołnierzy za posługi duszpasterskie ${ }^{9}$.

Biskup Polowy w swoich przemówieniach, kazaniach oraz w wypowiedziach okolicznościowych odwoływał się do bogactwa i mądrości zawartej na kartach Pisma Świętego. Teksty biblijne adaptował do wyjaśniania żołnierzom idei patriotyzmu. W swoich wypowiedziach często powracał do idei miłości Ojczyzny. Wskazywał na ogromne bogactwo i dziedzictwo Polski. Na to dziedzictwo składała się wiara w Boga, historia, kultura, język oraz tradycja. Wszystko to miało wielkie znaczenie w tworzeniu rodziny oraz narodu polskiego. Biskup Gawlina w przemówieniach do żołnierzy powracał wspomnieniami do rodzinnego domu, ojczystej ziemi. Żołnierzy wygnańców karmił nadzieją,

$7 \quad$ Kapelani wrześniowi. Stużba duszpasterska $w$ Wojsku Polskim w 1939 r. Dokumenty, relacje, opracowania, red. W. J. Wysocki i inni, Warszawa 2001, s. 47.

8 J. Odziemkowski, B. Spychała, Duszpasterstwo wojskowe w Drugiej Rzeczypospolitej, Warszawa 1987, s. 138. 
że prędzej czy później powrócą do Ojczyzny, do swoich bliskich, do domów. Celem używania wymienionych przykładów i porównań w wypowiedziach Biskupa Polowego było nie tylko podniesienie na duchu żołnierzy, lecz także jak najgłębsze dotarcie do duszy słuchaczy. Hierarcha w swoich przemówieniach nawiązywał do motywów zaczerpniętych z utworów Mickiewicza, Norwida, Sienkiewicza, do wielkich myślicieli jak Paweł Włodkowic, Andrzej Frycz Modrzewski, ks. Piotr Skarga. Żył sprawą polską, kochał Polskę, i te osobiste przekonania i wartości przekazywał żołnierzom. Nieustannie przypominał, iż przyjdzie dzień, kiedy powrócą do rodzinnych stron, gdy Ojczyzna odrodzi się na nowo. Zachęcał żołnierzy do żywej wiary, potwierdzonej czynem. Dużo uwagi przywiązywał do symboliki narodowej. W symbolach polskości widział ciągłość państwowości i tożsamości. Podkreślał rolę i znaczenie żołnierskiego sztandaru z napisem „Bóg - Honor - Ojczyzna”. Był głęboko przekonany, że autentyczny patriotyzm, czyli miłość do Ojczyzny winien być zgodny z wyznawaną wiarą chrześcijańską, nieustannie pogłębianą i umacnianą. Biskup Gawlina wskazywał na przykłady polskich bohaterów/patriotów/przywódców: m.in. Karola Chodkiewicza, Stefana Czarnieckiego, Jana III Sobieskiego, Józefa Poniatowskiego, Tadeusza Kościuszkę, Romualda Traugutta, Józefa Piłsudskiego, którzy w świadomości Polaków stanowili wzór żołnierskiego patriotyzmu ${ }^{10}$.

Biskup Gawlina zachęcał kapelanów, aby w posłudze duszpasterskiej kładli nacisk na wzmacnianie postawy moralnej, religijnej, i patriotycznej żołnierzy. W rozmowach z księżmi zachęcał do pracy nad

History of the Church odnową moralną żołnierzy. Między innymi na spotkaniu w Nottingham w maju 1941 roku z kapelanami lotników ks. Alojzym Kowalkowskim, Mikołajem Sasinowskim oraz mjr. lek. Aleksandrem Łuczakiem z 305 Dywizjonu Bombowego im. Marszałka Józefa Piłsudskiego hierarcha tylko wspominał o poważnych wykroczeniach żołnierzy w dziedzinie religijności i moralności, lecz także zachęcał kapelanów do pracy nad ich odnową moralną. Według Biskupa przyczyną tego stanu były m.in. ciężkie doświadczenia i pobyt w trudnych warunkach w obozach Rumunii i na Węgrzech w drodze do Francji. Żołnierze polscy doświadczali głodu, nędzy i brudu, obojętnego traktowania. To doprowadzało ich do rozpaczy po utracie Ojczyzny i swoich bliskich. Także od swoich rodaków doświadczali nienawiści i egoizmu. To ich przybijało, męczyło,

10 Por. J. Gawlina bp, Z wojny i z wygnania: listy i orędzia pasterskie, kazania, przemówienia, Rzym 1952; M. Wesołowski, Świętość żotnierza w nauczaniu Biskupa Polowego Józefa Gawliny, Warszawa 2003. 
popychało do alkoholizmu lub wstępowania do sekt, czy korzystania z usług domów publicznych ${ }^{11}$.

Biskup Gawlina wiele uwagi przywiązywał do służby Bogu i Ojczyźnie potwierdzanej poświęceniem, odwagą, nawet ryzykiem poniesienia najwyższej ofiary, czyli utraty życia. W kazaniu wygłoszonym do lotników, przed wybuchem wojny, w Dęblinie w 1937 roku jasno wyraził się na temat ceny miłości do Ojczyzny cytując słowa marszałka Ferdynanda Focha „miłość żąda ofiary”. Dużą rolę w patriotycznej postawie żołnierzy odgrywał honor ukierunkowany na konsekwentną służbę dobru, nawet za najwyższą cenę - utratę życia ${ }^{12}$.

Odwaga, męstwo, koleżeńskość, uczciwość, prawdomówność, odpowiedzialność, wierność, posłuszeństwo przełożonym były to cechy żołnierza, które świadczyły o jego wartości także bojowej. Niemniej istotnym było kształtowanie postawy patriotycznej żołnierzy na wzorcach z przeszłości Polski. Przekazywanie tradycji patriotycznej i wskazywanie na bogatą chwałę oręża polskiego miało na celu integrowanie żołnierzy oraz umacnianie więzi ze społeczeństwem. Dlatego oprócz zachęty do nawiązywania podczas różnorakich wystąpień i przypominana zrywów i powstań narodowych bp Gawlina zachęcał kapelanów, aby podczas wspólnego przeżywanie świąt religijnych, szczególnie Bożego Narodzenia i Wielkanocy wzmacniać wzajemne więzy oraz kształtować poczucie dumy narodowej.

\section{Posługa kapelanów wśród lotników}

Pośród żołnierzy Polskich Sił Powietrznych na Zachodzie posługiwało ponad 20 księży diecezjalnych i zakonnych. Chociaż zachowało się niewiele przemówień czy kazań skierowanych do żołnierzy tej formacji, to zasadniczo w każdym z nich zawarte były wątki religijne i patriotyczne. Tuż po klęsce kampanii wrześniowej część polskich żołnierzy udała się do Francji i Anglii, aby dalej kontynuować walkę z Niemcami. Wraz z nimi udali się także niektórzy księża, którzy wcześniej byli kapelanami wojskowymi lub też podjęli tę służbę poza granicami Polski.

Jednym z najtrudniejszych problemów, z którymi spotykali się duszpasterze było zwątpienie i rozgoryczenie oraz brak wiary na odrodzenie wolnej Polski. Przegrana kampania wrześniowa, w wyniku której wojska niemieckie i sowieckie zajęły Polskę dla wielu żołnierzy

$11 \quad$ M. Sasinowski, Dziennik, 8.5.1941, k. 314-318.

12 J. Gawlina, O honorze. Przemówienie w Stowarzyszeniu św. Tomasza z Akwinu $w$ Londynie, w lutym 1944 r., [w:] idem, Z wojny i wygnania..., s. 163-165.

History of the Church 
stała powodem do duchowego i moralnego załamania. Część z nich załamała się i utraciła nadzieję. Kapelani oraz dowódcy wojsk polskich na Zachodzie w swoich wypowiedziach nierzadko poruszali i analizowali przyczyny upadku Polski oraz opisywali stan morale żołnierzy. W liturgii oraz przy innych okazjach starali się podnosić żołnierzy na duchu, wzywali do nadziei i wiary w ponowne odzyskanie niepodległości. Jesienią 1939 roku pallotyn ks. Ignacy Olszewski - sekretarz Biskupa Polowego Józefa Gawliny oraz przyszły kapelan polskich lotników we Francji i Anglii we Mszach św. dla żołnierzy zachęcał, aby nie poddawali się, lecz wierzyli w odrodzenie się Ojczyzny:

Nie powinniśmy poddawać się zniechęceniu i zwątpieniu. Bowiem Naród Polski już niejeden raz musiał się organizować za granicą i tworzyć swoje rządy, np. najazd Szwedów - Jan Kazimierz, powstania i rozbiory Polski, obecnie. (...) Teraz Polska odzyska znów niepodległość. Tymczasem mamy pracować na każdym stanowisku, na każdym szczeblu, dla dobra Polski. Nie rozpaczać, nie narzekać, nie płakać, ale każdą czynność wykonać z myślą o Polsce ${ }^{13}$.

W kolejnych niedzielnych Mszach św. poruszał kwestię zaangażowania żołnierzy w przyszłą odbudowę Ojczyzny. Podkreślał, że do odnowy Polski potrzeba będzie wewnętrznej przemiany Polaków, ludzi odpornych na przeciwności, o silnych charakterach, posłusznych i obowiązkowych ${ }^{14}$. Jesienią 1939 roku ks. Mikołaj Sasinowski, kapelan lotników od lutego 1940 roku w swoim Dzienniku zanotował m.in. gorzkie spostrzeżenia na temat zachowania niektórych żołnierzy polskich we Francji. Po przybyciu do bazy Cöetquidan Camp, gdzie

History of the Church ks. Sasinowski nie otrzymał etatu kapelana, lecz służył jako instruktor wojskowy, zauważył, że część żołnierzy zabrała się z entuzjazmem do tworzenia i szkolenia oddziałów polskich, lecz jednocześnie coraz częściej w obozie dochodziło do intryg, walk, pijaństwa, niemoralnego prowadzenie się. Zdawał sobie sprawę, że trzeba wiele wysiłku, aby odbudować nadzieję i wiarę wśród żołnierzy, a nade wszystko dawać osobiste dobre świadectwo nadziei na lepszą przyszłość, wiary i patriotyzmu. Wprost i bez ogródek apelował do żołnierzy, aby:

13

14

M. Sasinowski, Dziennik, 22.10.1939, k. 53-54.

„Na nas - żołnierzach - ciąży wielkie zadanie: odbudowanie Ojczyzny i wymierzenie sprawiedliwości tym, co ją rozdarli i przyczynili się do rozdarcia. Do spełnienia tych zadań potrzeba wielkich środków. Te środki zdobyć musimy my. Tymi środkami jesteśmy my sami. (...) Musimy stać się ludźmi o silnym charakterze i stalowej woli. Żeby to zrobić należy się ćwiczyć w dwóch cnotach: posłuszeństwo (karność) i obowiązkowość”. M. Sasinowski,Dziennik, 5.11.1939, k. 64-66. 
...się pozbyli pleśni samolubstwa dogadzania swym własnym tylko zmysłom, czas byśmy stali się głosem narodu, pragnącego odrodzić się moralnie, byśmy wskazywali nowe drogi, oparte na etyce Chrystusowej drogi - prowadzące niezawodnie do wolnej i wielkiej Polski ${ }^{15}$.

Ksiądz Sasinowski wierzył, że ogrom cierpienia zaznanego przez Polaków może wywołać odrodzenie moralne żołnierzy, którzy w przyszłości, w oparciu o Boże zasady i wspólny wysiłek przyczynią się do odrodzenia państwa polskiego ${ }^{16}$. Uważał, że każde zło i zgorszenie popełnione przez polskich żołnierzy niszczyło mozolnie zdobyta opinię o prawości Polaków, wierności chrześcijańskim ideałom służby Bogu i Ojczyźnie. Do kapelana lotników niejednokrotnie dochodziły informacje o niegodnym postępowaniu żołnierzy rodaków, którzy uczęszczali do domów publicznych lub zdradzali swoje żony i zawierali nowe cywilne związki małżeństwie za granicą. Mówił o tym wprost i bez ogródek do żołnierzy:

Dziś w kazaniu (...) po prostu poniosło mnie. Pragnąłbym przecież, żeby ci nasi Polacy byli zawsze najlepsi, żeby zostawili tu jak najlepszą opinię. Naturalnie jest dużo takich, którzy to doskonale rozumieją, ale wśród tej ogólnej masy, zawsze się znajdzie jakiś wyrzutek, który nie tylko nie dba o swoją opinię, ale przynosi hańbę naszej Ojczyźnie ${ }^{17}$.

Ubolewał także nad stanem moralnym kadry oficerskiej. W jego przekonaniu był to owoc niewłaściwego wychowania duchowego oficerów II Rzeczypospolitej. W jednoznacznych słowach wyrażał swą dezaprobatę do siania zgorszenia i jednocześnie wzywał do bezwzględnej naprawy postaw kadry oficerskiej, od której przede wszystkim należałoby oczekiwać wzoru postępowania ${ }^{18}$.

\section{Krzewienie wiary}

Biskup Polowy Józef Gawlina, jako fundament żołnierskiej miłości do Ojczyzny postrzegał w praktykowaniu żywej wiary. W swoich kazaniach najpierw wyjaśniał Ewangelię, a następnie aktualizował jej treść w konkretnej sytuacji żołnierskiej. Dużo uwagi poświęcał związkowi między losami Ojczyzny i wiernością rodaków Bogu. Podobnie czynili inni kapelani. W posłudze duchowej kapelanów lotników zauważa się nieustannie odwoływanie się do Pana Boga. Wspomniany ks. Mikołaj

\footnotetext{
$15 \quad$ Ibidem, 28.1.1940, k. 156-161.

$16 \quad$ Ibidem. 28.1.1940, k. 156-161.

$17 \quad$ Ibidem, 7.4.1940, k. 198.

18 Ibidem, 4.8.1940, k. 269-270.
} 
Sasinowski w swoim Dzienniku często wyrażał głęboką wiarę w Boga i w Jego Opatrzność. W przepowiadaniu ściśle wiązał dwie rzeczywistości: Boga i Ojczyznę. Jesienią 1939 roku wyraził swoiste wyznanie wiary:

Dla mnie są dwie rzeczy najważniejsze, za które gotów jestem zawsze przelać swoją krew, to jest Bóg i Ojczyzna. Zarówno jak za Boga w obronie Jego godności, w obronie swojej świętej wiary, tak również i w obronie mej drogiej Ojczyzny gotów jestem do największych poświęceń, nie wyłączając swego życia. W wojnie dzisiejszej chodzi przecież o Boga i Ojczyznę. Bóg jest sponiewierany, wyszydzony. Wiara święta jest prześladowana ${ }^{19}$.

Modlił się za żołnierzy i umacniał nadzieją: „Modlę się za was ustawicznie, o Bracia. Polacy. Bóg da nam zwycięstwo - wierzcie"20. Był głęboko przekonany, że w przyszłości Polska odrodzi się na nowo. Aby tak się stało trzeba było, aby naród polski był silny, zdrowy duchowo i fizycznie, połączony w jednym państwie, szedł drogą prawdy, prawa i honoru ${ }^{21}$. Także i inni duchowni, którzy odwiedzali polskich żołnierzy, jak choćby kard. Pierre Marie Gerlier - prymas Francji spotykając polskich lotników w Lyonie zachęcał do nadziei i wiary:

...dzięki Bogu i Maryi Polska się odrodzi (...), albowiem (...) z nami jest Bóg i Matka Najświętsza. I właśnie ten wszechmocny i potężny Bóg wraz z Matką Najświętszą - waszą Królową, wybawią Polskę z jej ciężkiej sytuacji, a ramię żołnierza polskiego okryje na nowo nieśmiertelną aureolą chwały i zwycięstwa ${ }^{22}$.

Ksiądz Sasinowski wierzył, że pomimo kolejnej katastrofy, jaką była

History of the Church

niemiecka inwazja na Francję każdy, kto cała ufność położył w Bogu - nie zawiedzie się. Ufał, że Bóg przyjdzie Polakom z pomocą i stanie w obronie zniszczonych kościołów i sprofanowanych ołtarzy i że nawet z najgorszej sytuacji potrafi wydźwignąć, a jednocześnie poniżyć ludzi nieprawych. Był głęboko przekonany, że tylko Bóg nie zawiedzie i dlatego w Nim pokładał nadzieję i wierzył mocno, że Polska kiedyś będzie wolna. Podczas podróży morskiej z Gibraltaru do Anglii codziennie modlił się z lotnikami o bezpieczną podróż. Po dopłynięciu do Glasgow zachęcał żołnierzy, by dziękowali Bogu za to, że towarzyszył w drodze, zachował od nalotów bombowych, które miały miejsce. Tę wdzięczność żołnierze winni Stwórcy okazywać poprzez uczciwie

\footnotetext{
19 Ibidem, 8.9.1939, k. 13-14.

$20 \quad$ Ibidem, 11.9.1939, k. 18-20.

$21 \quad$ Ibidem, 17.9.1939, k. 24-27.

$22 \quad$ Ibidem, 3.5.1940, k. 207-211.
} 
i solidnie wykonywanie swoich obowiązków, które Bóg i Ojczyzna im powierzyli: wiernie przestrzegać praw Bożych i dbać o dobre imię i chwałę Ojczyzny.

Kapelan duchowo towarzyszył lotnikom podczas ich lotów operacyjnych na Niemcy i tereny okupowane. Kiedy dowiadywał się o zbliżającym się terminie nalotów bombowych, sami dowódcy prosili go o nabożeństwo w intencji lotników. Zapisał w Dzienniku:

Ogromnie się tym ucieszyłem, że chcą rozpocząc pracę z Bogiem. Oświadczyłem, że sam nosiłem się z podobną myślą. Ponieważ jednak są to rzeczy owiane jakąś dziwną tajemnicą - więc dotychczas nie poruszałem ich. Dzisiaj jednak zapewniam, że z prawdziwą radością to nabożeństwo zrobię i sam gorąco modlić się będę do Boga o błogosławieństwo dla was. Dziś właśnie o godzinie 20:30 siedem naszych załóg ma lecieć na Rotterdam. Powiedziałem im przeto, że przed lotem będzie króciutkie nabożeństwo dla nich. Przyszło dość sporo. Prawie wszyscy. Odmówiłem litanię do Matki Najświętszej i inne modlitwy okolicznościowe, powiedziałem kilka gorących słów zachęty do wytrwania i odwagi w tej walce. W końcu udzieliłem im ,absolucji” na wypadek, gdyby któregoś miałaby spotkać śmierć. Byli bardzo wdzięczni. Niektórym pokazały się łzy. Modlili się naprawdę gorąco. Poszli ... zostałem sam w kaplicy odmawiając Różaniec za nich. Prosiłem Matkę Najświętszą by wyjednała u Boga łaskę powrotu dla wszystkich. Jest to pierwszy lot. Przywiązuję do niego wielką wagę. Od tego pierwszego lotu zależeć będzie wiele w dalszej pracy. Maszyny zaczynają startować... przed tym strzelcy próbują swoich karabinów, czy sprawnie pracują. Wreszcie po nabraniu pewnej wysokości biorą kurs i ciągną nad drogą. Cały czas stałem w lasku obok, modląc się gorąco za nich, za ich powrót, za całość ich maszyn i za ich zdrowie. Całą noc czuwałem z lekarzem na lotnisku. Byłem przy ich powrocie. Poszedłem spać dopiero, jak wszystkie załogi powróciły. Położyłem się spać około godziny 4tej nad ranem byłem dość zmęczony. Bo wstałem jutro jak zwykle wcześnie, czyli o godzinie 7ej odprawić Mszę św. 23

Ksiądz Sasinowski odczuwał wielką radość w chwilach, gdy polscy lotnicy, mimo wielkich strat osobowych dawali świadectwo wiary. Był blisko związany z nimi, a nawet osobiście uczestniczył w akcjach operacyjnych. Oto relacja z 5 kwietnia 1941 roku:

Pogoda cudna. Przypadkowo trafiam do hangaru 305 dywizjonu.(...). Któryś z oficerów proponuje mi lot na bombardowanie nad morze. Chętnie się zgadzam. Startujemy. Maszyna się podrywa. Jakiś dreszczyk przebiega po kościach. Jakoś myśl przelatuje po głowie: „,cofać się już za późno. Trochę żal odrywać się od ziemi”. Ale to przecież tylko chwilowe, wyobraźnie skierowuje się na co innego. Obserwuję pilota, 
jak dusi maszynę, jak ją ściąga, jak zadziera jej dziób coraz wyżej. Ziemia ucieka spod nóg, wznosimy się coraz wyżej. Nabieramy wysokości, wiatr coraz silniej dmie od morza. Małe kłęby chmur przemykają pod stopami, a my ciągle na przód. Niedaleko morza jakiś większy zwał chmur. Tak cudnego widoku jeszcze nigdy nie widziałem. Nie da się nawet porównać z naszymi górami, pokrytymi śniegiem w zimie. Coś tak cudnego jak z bajki. Teraz dopiero odczułem jak piękna jest służba w lotnictwie. Po rzuceniu bomb - wróciliśmy na obiad do domu. Byłem dwie godziny w powietrzu. Obecnie mam już za sobą ponad siedem godzin lotu ${ }^{24}$.

Szczególnie ważnym wydarzeniem duszpasterskim dla kapelanów lotników były Zaduszki, podczas których modlono się za poległych żołnierzy w jednostkach lub publicznie na cmentarzach lotników polskich. Wspomnienie przeżywane ze wzruszeniem miało charakter patriotyczno-religijny ${ }^{25}$. Modlono się za tych, którzy nie oszczędzili swego życia, oddali za Polskę swoją krew w ofierze Ojczyźnie.

\section{Honor}

Istotnym elementem formacji żołnierzy było kształtowanie postawy honoru. Pierwszym, który w czasach starożytnych opisał tę cechę był Arystoteles. Według filozofa była to postawa życia moralnego człowieka, który odbierał cześć - zapłatę za postępowanie nacechowane pełnią cnót ${ }^{26}$. Honor w życiu żołnierza jest wewnętrznym pozytywnym aktem, nakierowanym na dobro służby Ojczyźnie. Kapelani kładli duży nacisk na kształtowanie honoru. Argumentowali, że Polacy w historii

History of the Church wielokrotnie okazywali się ludźmi honoru, który budowali poprzez duchowe i zewnętrzne zmaganie. Honor traktowali jako element wierności służbie Bogu i Ojczyźnie. Ksiądz Sasinowski w jednym z kazań apelował do żołnierzy:

Bracia (...) mam nadzieję, że nie przyniesiecie wstydu Polsce, że przeciwnie, sztandar jej będziecie wysoko dźwigać. Polak jest zawsze honorowy. Jesteście synami tej Ojczyzny, która pierwsza stanęła w obronie honoru. Dziś Kościół i Polska liczy na wasz honor. Jestem pewny, że przez swoją uczciwą i solidną pracę zasłużymy na rychłe zwycięstwo ${ }^{27}$.

$24 \quad$ Ibidem, 5.4.1941, k. 309-310.

25 „Zaduszki. Święto Zmarłych. Mszę św. odprawiłem za wszystkich drogich braci Polaków, który nie wahali się swojej krwi przelać w obronie wolności drogiej Matki - Ojczyzny. Niech im dobry Bóg da wieczną nagrodę za ich poświęcenie, cierpienie i odwagę." Ibidem, 2.11.1940, k. 292.

$26 \quad$ Por. Arystoteles, Etyka nikomachejska, Warszawa 1995, IV 3, 1123 b 35.

$27 \quad$ M. Sasinowski, Dziennik, 26.11.1939. k. 81-87. 
Podczas składania przysięgi przez podchorążych, których sam, szkolił jako instruktor wojskowy przedstawił sens jej poszczególnych elementów:

Przysięgam Panu Bogu Wszechmogącemu, Trójcy Świętej Jedynemu, być wiernym Ojczyźnie mej, Rzeczpospolitej Polskiej, sztandarów wojskowych nigdy nie odstąpić, stać na straży konstytucji i honoru żołnierza Polskiego. (...). Honor - to uczciwość, rzetelność, poczucie własnej godności. Jesteście spadkobiercami wielkich bohaterów. Ojczyzna nam powierzyła honor. Nie wolno nam go zdradzić. (...). Rozkazy dowódców. Wojsko opiera się na honorze ${ }^{28}$. Honor żołnierski - nie wolno wam złamać przysięgi, którą składacie Bogu najwyższemu i Ojczyźnie, nie wolno wam splamić pięknego zaszczytnego munduru żołnierza polskiego, który przez bohaterskie walki kolegów naszych okryty jest nimbem chwały ${ }^{29}$.

Szczególnie ważnym symbolem dla żołnierzy był sztandar. 16 lipca 1941 roku na lotnisku Swinderby, w święto Matki Boskiej Szkaplerznej - patronki Polskich Lotników i w święto Polskich Lotników, Biskup Polowy Józef Gawlina poświęcił nowy sztandar lotników. Ksiądz Sasinowski - świadek uroczystości spisał jej przebieg:

Sztandar jest naprawdę cudny. Tak pięknego wykonania jeszcze nie widziałem w swoim życiu. Kolory polskie. Z jednej strony Matka Boska Częstochowska a z drugiej Ostrobramska. Cudnie wykonana. Włożyły tam one naprawdę cały swój artyzm. W nogach odznaki naszego lotnictwa Polskiego. Pod obrazem słowa: Bóg, Honor i Ojczyzna. Po drugiej stronie: św. Terenia od dzieciątka Jezus - piękna również. Pod spodem słowa: Miłość żąda ofiary. Istotnie - ta ofiara, którą złożyły za siebie nasze Polki, świadczy najdokładniej o ich miłości do Polski i do wszystkiego co Polskie, świadczy o tym jednocześnie, że ich czyn podejmowany z głęboką wiarą o moc Bożą nie będzie daremny, że dotrze tam, gdzie go przeznaczono, że naszą brać żołnierską będzie podtrzymywał na duchu i prowadził do zwycięstwa ${ }^{30}$.

Inicjatorem wykonania sztandaru Polskich Sił Powietrznych był dawny dowódca Eskadry Ćwiczebnej Obserwatorów z przedwrześniowego Centrum Wyszkolenia Lotnictwa nr $1 \mathrm{w}$ Dęblinie kpt. pil. Jan Hryniewicz. Projekt sztandaru zrealizowali pchor. pil. Kazimierz Karaszewski i pchor. pil. Zbigniew Wojda. Rysunki te zostały następnie przesłane przy pomocy tajnej poczty z Lyonu przez Sztokholm do Wilna. W Wilnie zawiązał się społeczny komitet wykonania sztandaru

$28 \quad$ Ibidem, 28.1.40, k. 156-161.

$29 \quad$ Ibidem, 19.5.1940, k. 215-216.

$30 \quad$ Ibidem, 16.7.1941, k. 335-338.

History of the Church 
pod kierownictwem dr Zofii Wasilewskiej-Świdowej i ks. Kazimierza Kucharskiego. Prace przy hafcie zostały wykonane przez siostry zakonne z klasztoru Benedyktynek i Zakładu Świętego Kazimierza. Sztandar PSP dotarł na Wyspy Brytyjskie dzięki konsulowi japońskiemu w Kownie Sugihara, który tajną pocztą dyplomatyczną przewiózł do Sztokholmu. Stamtąd został dostarczony do Wielkiej Brytanii 4 marca 1941 roku. Podczas uroczystość na lotnisku Swinderby kpt. Hryniewicz wręczył sztandar gen. Lucjanowi Żeligowskiemu, który przekazał go Premierowi i Wodzowi Naczelnemu gen. broni Władysławowi Sikorskiemu. Generał Sikorski wręczył sztandar Inspektorowi Polskich Sił Powietrznych (dowódcy) gen. bryg. obs. Stanisławowi Ujejskiemu, ten zaś dowódcy 300 Dywizjonu Bombowego im. Ziemi Mazowieckiej ppłk. pil. Wacławowi Makowskiemu. Sztandar poświęcił Biskup Polowy WP Józef Gawlina w obecności księży kpt. Mikołaja Sasinowskiego i Ignacego Olszewskiego. Był on przekazywany co trzy miesiące kolejnemu polskiemu dywizjonowi lotniczemu na terenie Wielkiej Brytanii ${ }^{31}$.

\section{Ojczyzna}

Jednym z najważniejszych i najszerzej podejmowanych wątków przez kapelanów lotników PSP była tematyka miłości do Ojczyzny. Po klęsce wrześniowej kapelani motywowali żołnierzy do walki, która w przyszłości miała zapewnić wolność Polski. Nieśli nadzieję i zachętę i wiarę, że Ojczyzna znowu będzie niepodległa. W okresie zniechęcenia z powodu porażki, szczególnie - jesienią 1939 roku zachęcali rodaków do nadziei na odzyskanie wolności, którą można zrealizować tylko przez pracę dla dobra Polski, a nie przez samo narzekanie. Wzywali do pracy nad sobą, do stawania się silnymi ludźmi z silnym charakterem o mocnej woli. W swoich kazaniach i innych wypowiedziach do żołnierzy o miłości do Ojczyzny wiązali ją z miłością do Boga. W swoim Dzienniku ks. Sasinowski po przybyciu do bazy lotniczej we Lyonie zapisał: „Cieszę się z tego jednego bardzo, bo raz, że mam dużo wewnętrznej satysfakcji, że pracuję owocnie dla Boga i Ojczyzny"32.

Podczas ewakuacji z Francji przez Afrykę i Gibraltar kapelan nieustannie umacniał żołnierzy. Tułaczkę pełną niepewności zawierzał

\footnotetext{
$31 \quad$ Ibidem.

$32 \quad$ Ibidem, 3.3.1940, k. 187-193.
} 
$\mathrm{Bogu}^{33}$. Podczas niebezpieczeństw podróży morskiej z Gibraltaru do Anglii modlił się z lotnikami w intencji Ojczyzny ${ }^{34}$.

Wdzięczność (Bogu) okażemy najlepiej, jeżeli uczciwie i solidnie będziemy wykonywali swoje obowiązki, które on i Ojczyzna nam powierzyli, jeżeli będziemy wiernie przestrzegali praw bożych, jeżeli będziemy dbali gorliwie o dobre imię i sławę ukochanej i umęczonej Ojczyzny ${ }^{35}$.

Kapelani nawiązując do miłości Ojczyzny wzywali lotników do godnego postępowania w życiu osobistym. Ostro występowali przeciwko łamaniu praw Bożych. Od przemiany duchowej, do której nieustannie wzywał, niejako uzależniał powrót do wolnej Ojczyzny.

Moralność naszego wojska - a szczególnie oficerów pozostawia wiele do życzenia. Jeżeli nam pozwoli Bóg wejść do Ojczyzny - to przede wszystkim należy się domagać bezwzględnej naprawy w wojsku ${ }^{36}$.

Swoją posługę kapelańską polscy księża w Anglii pełnili wśród lotników dywizjonów myśliwskich i bombowych. Cytowany często ks. Mikołaj Sasinowski posługiwał w 304 Dywizjonie Bombowym „Ziemi Śląskiej im. Ks. Józefa Poniatowskiego” i 305 Dywizjonie Bombowym „Ziemi Wielkopolskiej im. Marszałka Józefa Piłsudskiego”. Polskie Dywizjony Bombowe w Wielkiej Brytanii podczas wojny poniosły trzykrotnie większe straty osobowe w trakcie działań operacyjnych niż wszystkie pozostałe jednostki - dywizjony myśliwskie.

\section{Zakończenie}

Wszyscy kapelani Polskich Sił Powietrznych na Zachodzie lotnicy byli kapłanami rzymskokatolickimi. Sprawowali opiekę duszpasterską nad żołnierzami służącymi w jednostkach lotniczych w bazach RAF, przypisanymi do danego rejonu duszpasterskiego. Do ich obowiązków należało odprawianie niedzielnych i świątecznych Mszy św., udzielanie ślubów i chrztów, błogosławienie małżeństw, odwiedzanie chorych i rannych w szpitalach, odprawianie uroczystości pogrzebowych, a także spowiedź, opieka i wsparcie duchowe żołnierzy lotnictwa. Służyli Polakom, którzy walczyli oddaleni od swych rodzin, często bez żadnych wiadomości na ich temat od chwili wybuchu wojny. Jeśli nawet kontakt $\mathrm{z}$ rodziną udało się nawiązać, i tak u żołnierzy pozostawała troska i niepewność o przyszłość najbliższych, żyjących pod niemiecką i sowiecką

\footnotetext{
$33 \quad$ Ibidem, 18.6.1940, k. 237.

34 Ibidem.

$35 \quad$ Ibidem, 21.7.1940, k. 261-264.

$36 \quad$ Ibidem, 4.8.1940, k. 269-270.
}

History of the Church 
okupacją. Kapelani musieli więc dokładać starań, aby podtrzymywać ducha w szeregach wojska. Odegrali znaczna rolę nie tylko w formacji duchowej i religijnej, lecz także patriotycznej. Celem tej formacji było kształtowanie dojrzałej postawy chrześcijańskiej żołnierzy, a także głębokiej miłości do Ojczyzny, czyli patriotyzmu.

\section{FORMACJA PATRIOTYCZNA ŻOŁNIERZY POLSKICH SIŁ POWIETRZNYCH NA ZACHODZIE (1939-1945)}

Po katastrofie kampanii wrześniowej w 1939 roku wielu polskich żołnierzy udało się do Francji i Wielkiej Brytanii w celu kontynuowania walki z Niemcami. Wśród nich pokaźną grupę stanowili lotnicy. Dla nich Biskup Polowy Józef Gawlina zorganizował specjalne duszpasterstwo, złożone z kilkudziesięciu księży diecezjalnych i zakonnych. W swoich dokumentach, kazaniach i innych wystąpieniach hierarcha wydawał praktyczne wskazówki dotyczące istotnych elementów posługi duszpasterskiej. Wśród nich, oprócz wątków ściśle religijnych, zalecał także ustawiczną formację patriotyczną. Dotychczas, poza wyjątkami, niewielu badaczy zajmowało się tym specyficznym rodzajem duszpasterstwa (A. F. Kowalkowski, J. Łupiński, W. Zmyślony). Autor niniejszej publikacji, na podstawie Dziennika ks. Mikołaja Sasinowskiego oraz innych dostępnych źródeł, analizuje realizację postulatu bp. J. Gawliny formacji duszpasterskiej i patriotycznej wśród polskich lotników.

Słowa kluczowe: Il wojna światowa, Polskie Siły Powietrzne, Francja, Wielka Brytania, kapelani wojskowi, formacja religijna i patriotyczna.

History of the Church

\section{Bibliografia:}

1. Arystoteles, Etyka nikomachejska, Warszawa 1995.

2. Gawlina J., O honorze. Przemówienie w Stowarzyszeniu św. Tomasza z Akwinu w Londynie, w lutym 1944 r., [w:] idem, Z wojny i z wygnania: listy i orędzia pasterskie, kazania, przemówienia, Rzym 1952.

3. Gawlina J., Z wojny i z wygnania: listy i orędzia pasterskie, kazania, przemówienia, Rzym 1952.

4. Kowalkowski A. F., Duszpasterstwo Polskich Sit Powietrznych we Francji i w Wielkiej Brytanii 1939-1946, „Studia Pelplińskie” 1979.

5. Odziemkowski J., Spychała B., Duszpasterstwo wojskowe w Drugiej Rzeczypospolitej, Warszawa 1987.

6. Przedmowa J. E. Księdza Biskupa Dr. Mikołaja Sasinowskiego, b. kapelana P.S.P., [w:] A. F. Kowalkowski, Duszpasterstwo Polskich Sit Powietrznych we Francji i w Wielkiej Brytanii 1939-1946, „Studia Pelplińskie” 1979. 
7. Sasinowski M., Dziennik, 26.10.1939, mps w Archiwum Diecezjalnym w Łomży (dalej ArŁm), Akta Biskupa Mikołaja Sasinowskiego.

8. Wysocki W. J. i inni red., Kapelani wrześniowi. Stużba duszpasterska w Wojsku Polskim w 1939 r. Dokumenty, relacje, opracowania, Warszawa 2001.

9. Wesołowski M., Świętość żotnierza w nauczaniu Biskupa Polowego Józefa Gawliny, Warszawa 2003. 